
\title{
R Research S Surare \\ Root exudate input stimulates peatland recalcitrant DOC decomposition by r-strategic taxa of Gammaproteobacteria and Bacteroidetes
}

Jiř́ Mastný ( $\square$ mastny.jiri@seznam.cz )

Jihoceska Univerzita v Ceskych Budejovicich https://orcid.org/0000-0002-5239-5783

Jiří Bárta

Jihoceska Univerzita v Ceskych Budejovicich Prirodovedecka Fakulta

Eva Kaštovská

Jihoceska Univerzita v Ceskych Budejovicich Prirodovedecka Fakulta

Tomáš Picek

Jihoceska Univerzita v Ceskych Budejovicich Prirodovedecka Fakulta

\section{Research}

Keywords: DOC decomposition, priming effect, peatland, DOC, r-strategic bacteria, microbial community, microbial functions

Posted Date: January 17th, 2020

DOI: https://doi.org/10.21203/rs.2.21088/v1

License: (9) This work is licensed under a Creative Commons Attribution 4.0 International License. Read Full License 


\section{Abstract}

\section{Background}

In peatlands, decomposition of organic matter is limited by harsh environmental conditions and low decomposability of the plant material. Increased microbial decomposition of organic matter in peatland ecosystems may become an important phenomenon in the near future after the expected shift in plant community composition from Sphagnum to vascular plants due to climate change. Such a change in plant community composition will lead to increased root exudates flux to the soil and stimulation of microbial growth and activity. The aim of our study was to evaluate the effect of root exudates on the decomposition of recalcitrant dissolved organic carbon (DOC) and identify the microorganisms responsible for this process.

\section{Results}

Decomposition of recalcitrant DOC was stimulated by a high levels of $13 \mathrm{C}$ labelled root exudates addition whereas it was suppressed by a low levels of root exudates addition. Recalcitrant DOC decomposition was positively related to the exudate $\mathrm{C} / \mathrm{N}$ ratio as a result of enhanced "microbial nutrient mining" due to a deepening of microbial nutrient limitation. The early stage of incubation immediately following the exudate addition was characterized by the preferential use of the added compounds at the expense of recalcitrant DOC. At the same time, r-strategic bacteria (identification based on average 16SrRNA gene copy number) belonging to mainly to Gammaproteobacteria and Bacteriodete s phyla relatively increased within the microbial community. At the later stage, this more abundant bacterial community was replaced by a less abundant community composed of bacteria mostly belonging to Alphaproteobacteria and Acidobacteria. The most important taxa with the potential to decompose complex compounds were indentified: Mucilaginibacter (Bacteriodete s), Burkholderia and Pseudomonas ( Gammaproteobacteria) among r-strategists and Bryocella and Candidatus Solibacter ( Acidobacteria) among K-strategists.

\section{Conclusions}

Increased inputs of root exudates, with a higher $\mathrm{C} / \mathrm{N}$ ratio, may stimulate decomposition of peatland recalcitrant DOC. In this, bacteria were found to be more important than fungi. Our experiment indicates that $\mathrm{r}$-strategic bacteria as well as $\mathrm{K}$-strategists can be important in stimulated decomposing of recalcitrant peatland DOC.

\section{Background}

In the peatlands, decomposition of soil organic carbon (SOC) is restricted due to prevailing anoxic conditions, low pH, nutrient limitation and low decomposability of the plant material. Consequently, peatland dissolved organic carbon (DOC) is also hardly decomposable and referred as recalcitrant [1]. Peatlands thus represent a substantial source of DOC to aquatic ecosystems [2,3]. Vascular plants and 
mosses release variety of organic compounds from their roots and steles including low molecular weight and easily decomposable exudates, such as organic acids, sugars and amino acids [4]. Such compounds stimulate microbial growth and activity, including a production of extracellular enzymes, which may accelerate decomposition of peat and peatland DOC - a phenomenon called positive priming effect (PE) $[5,6]$. Positive PE has been reported in peatland ecosystems $[7,8]$, but its significance is considered as minor [8] or unclear [7]. However, the ongoing climate change causes a spreading of vascular plants, namely graminoids and ericoids, in Sphagnum-dominated peatlands [9-11]. The enhanced root exudation associated with the vegetation shift can increase a role of positive PE in dynamics of peatland C cycle [12].

The exudates input to the soil commonly stimulates decomposition of pre-existing organic matter, causing a positive PE. However, a negative or no PE can also occur. A meta-analysis of data from terrestrial ecosystems [13] showed that addition of simple organic compounds could cause both deceleration (down to 50\%) and acceleration of SOC decomposition (up to $400 \%$ ). Similarly, a modelled $\mathrm{PE}$ of simple organic compounds on recalcitrant DOC in aquatic ecosystems ranged from $-130 \%$ to $+370 \%$ [14]. Although the impact of easily decomposable compounds on decomposition significantly varies among systems, it can be generalized that the extent and direction of induced PE is influenced by the amount and type of entering organic compounds $[15,16]$. Generally, a low input of easily decomposable compounds rather leads to negative or no $\mathrm{PE}$, while the high labile $\mathrm{C}$ addition can induce strong positive priming [17] and organic acids stimulate SOC decomposition more than carbohydrates [18]. Besides organic acids and carbohydrates, root exudates also contain $N$ in organic [19] and inorganic forms [20]. C-rich root exudation stimulates microbial growth and enhances $\mathrm{N}$ and $\mathrm{P}$ demand to build the biomass [21,22], which may lead to enzymatic nutrient mining from native SOC and DOC $[21,23]$. Accordingly, increasing positive $\mathrm{PE}$ was found with increasing $\mathrm{C} / \mathrm{N}$ ratio of exudates [24] and under soil $\mathrm{N}$ limitation compared to replete $\mathrm{N}$ conditions [25]. The phenomenon of nutrient mining from native DOC after entering of $\mathrm{C}$-rich exudates could play an important role in nutrient limited peatland ecosystems.

In peatlands, Sphagnum mosses are accompanied by vascular plants inhabiting microsites with lower water level. The peatland species differ in exudation flux and composition, and additionally, there is also a temporal variation in exudation as shown by [26]. Comparing three peatland species, they found the highest exudation rate for Eriophorum vaginatum, lower for Vaccinium myrtillus and the lowest for Sphagnum fallax. The identified exudates were dominated by organic acids with much lower contribution of sugars and amino acids. Their $\mathrm{C} / \mathrm{N}$ ratio ranged from 8 to 80 , with Sphagnum exudates being of higher $\mathrm{C} / \mathrm{N}$ ratios compare to Eriophorum and Vaccinium exudates, which contained more organic and inorganic $\mathrm{N}$. The exudate $\mathrm{C} / \mathrm{N}$ ratio of all species increased from spring to autumn. Root exudation of vascular plants contributed from 1 to $5 \%$ to the peatland DOC [26].

The root exudates entering the soil influence the composition and functioning of the rhizosphere microbial community and cause its successional changes. First it stimulates the growth of r-strategists [27], commonly Gram-negative bacteria such as Gammaproteobacteria and Bacteriodetes but also fungi [28]. Due to a fast growth, this population requires sufficient amounts of $\mathrm{N}$ and $\mathrm{P}$, which is immobilized in 
its biomass $[29,30]$. After depletion of easily degradable compounds, r-strategists die-back and their products and necromass serves as a substrate for a development of K-strategic population (contributed e.g. by Acidobacteria and Planctomycetes) [31,32]. Because the K-strategists utilize more complex substrates, the need to produce extracellular enzymes, which may lead to a targeted or co-metabolic decomposition of pre-existing, more stable SOC and finally result in positive PE [33,34]. The composition of microbial community actively utilizing the present substrates, its succession and a potential contribution of particular bacterial and fungal representatives to PE depend not only on the quantity and quality of entering exudates but also on initial composition of microbial community [35]. Because of the prevailing microaerophilic or anaerobic nature of peatlands, bacteria dominate the microbial community [36,37], while fungi are highly suppressed, and their abundance increases only in oxic microsites [38]. It is therefore likely that bacteria will play dominant role in decomposition of exudates, recalcitrant peatland DOC and in the PE, which may be induced by root exudates input.

In this study, we incubated peatland water with original recalcitrant DOC under laboratory conditions together with a mixture of organic compounds simulating root exudates input. The exudate addition differed in quantity $(2 \%$ or $5 \%$ of present $\mathrm{DOC})$ and in the $\mathrm{C} / \mathrm{N}$ stoichiometry $(\mathrm{C} / \mathrm{N}$ ratios $7,25,50)$ simulating different scenarios of root exudation of peatland plant species during vegetation season (according to [26]). We aimed to (i) evaluate the effect of the input and $\mathrm{C} / \mathrm{N}$ ratio of root exudates on recalcitrant DOC decomposition with a focus on its dynamics and resulting $\mathrm{PE}$, (ii) identify the compositional and functional changes in microbial community during the exudate and DOC decomposition and (iii) to link the potential positive PE with microorganisms responsible for this process.

Based on the literature survey we hypothesized:

i. Addition of exudates will stimulate decomposition of recalcitrant peatland DOC resulting in a positive PE. The positive PE will increase with increasing level of added exudates and their increasing $\mathrm{C} / \mathrm{N}$ ratio.

ii. Addition of exudates to DOC will lead to successional changes in the present microbial community: Initially, the presence of fresh exudates will increase the abundance of r-strategic species, while later the proportion of K-strategist will increase albeit the community will be smaller. Namely, K-strategic species with a larger potential to produce extracellular enzymes will be responsible for the positive PE.

\section{Results}

\section{Total respiration rates and priming effect}

Samples with exudate addition had initially lower total respiration rates than control (original peatland water) (Fig. 1 a, b). However, from day 2, the enriched samples respired significantly more than control. The stimulation effect of exudate addition on total respiration rate was higher and lasted longer for $5 \%$ exudates level than for $2 \%$ level. Specifically, samples with $2 \%$ exudate level respired more than control 
only till day 4 (Fig. 1 a), while samples with 5\% exudates level till day 11 (Fig. 1 b). The exudate C/N ratio did not affect total respiration rate in any treatment and on any time. After 25 days of incubation, from 17.1 to $23.5 \%$ of total C (DOC + exudate $\mathrm{C}$ ) were transformed to $\mathrm{CO}_{2}$.

The priming effect (PE) on DOC induced by exudate addition was dynamic in term of time. The addition of exudates at both concentrations initially induced negative PE (Fig. 1 c, d) till day 4, whereas later between day 4 and 11 , the PE turned to significantly positive for $5 \%$ exudate level $(p<0.001)$. The exudates with $\mathrm{C} / \mathrm{N}$ ratio of 50 induced larger positive $\mathrm{PE}$ as compared to the exudates with lower $\mathrm{C} / \mathrm{N}$ on the day $11(p<0.01)$ and only that one remained positive also on the day $25(p<0.05)$ (Fig. 1 d). Differently, no PE or slightly negative PE was measured for $2 \%$ exudate addition till the end of experiment, with no effect of exudate $\mathrm{C} / \mathrm{N}$ ratio on PE (Fig. $1 \mathrm{c}$ ). The final PE ranged from -7.9 to $-1.2 \%$ for low exudates level while the PE from 3.2 to $19.9 \%$ was measured for high exudates level. Significantly higher PE values were found for $\mathrm{C} / \mathrm{N}$ ratio 50 than 7 for high level of exudates addition.

\section{Nutrient concentrations as affected by exudates addition}

Concentration of ammonium $\mathrm{N}$ in soil solution of samples enriched with exudates significantly decreased during first four days (except $2 \%$ exudates with $\mathrm{C} / \mathrm{N}$ ratio 7$)(\mathrm{p}<0.001)$ and then slowly increased back close to its original levels till day 25. Similar dynamics of ammonium $\mathrm{N}$ occurred also in the control but the changes were much less pronounced and the decrease lasted till day 11 (Fig. 2 a, b). Differently, no significant changes were found for nitrate (Additional file 1: Figure S1). Soluble reactive phosphorus (SRP) concentration decreased in time $(p<0.001)$, with the fastest decline between day 0 and 4 , followed by relatively stable phase between day 4-11 and another but slower decrease till the end of incubation (Fig. 2 c, d). The decline of SRP in the solution was more pronounced under $5 \%$ than $2 \%$ level of exudates addition $(p<0.001)$. The SRP declined also in controls but the decline was stable, without an initial sharp stage. After 25 days of the incubation, samples with $5 \%$ exudates had still significantly lower SRP concentration than control, while those with $2 \%$ exudates did not differ from the control $(p<0.01)$.

\section{Temporal changes in abundance and composition of microbial communities}

Generally, microbial community in peatland water was dominated by bacteria. Fungi formed a minor part of microbial community, which is shown by an extremely low fungi to bacteria ratio ( $\mathrm{F} / \mathrm{B}$ ratio), which ranged from $1.15^{\star} 10^{-5}$ to 0.026 (Additional file 2: Figure S2). Further, bacterial abundance was more dynamic than fungal one after exudate addition. Abundance of bacterial marker gene increased during the first 4 days of incubation (Fig. 3). This growth was followed by a significant decrease till day 11 for $5 \%$ level addition (Fig. 3 b). For $2 \%$ level addition, the bacterial abundance was similarly dynamic only for exudates with $\mathrm{C} / \mathrm{N} 50$, while did not change significantly for other exudate $\mathrm{C} / \mathrm{N}$ ratios (Fig. 3 a). Fungal abundance increased from day 11 till day 25 and, therefore, the F/B ratio increased compare to original 
conditions $(\mathrm{p}<0.05)$ (Fig. 3 a, b). Finally, samples with both $2 \%$ and $5 \%$ exudate addition had higher F/B ratio than control and, additionally, those enriched with exudates with $\mathrm{C} / \mathrm{N}$ ratio of 7 had higher $\mathrm{F} / \mathrm{B}$ ratios than other treatments $(p<0.01)$.

Bacterial community composition significantly changed in time under both levels of exudate addition, being unique each sampling day. The temporal changes of bacterial community composition explained $31.7 \%$ of data variability in samples with $2 \%$ exudate addition and $59.7 \%$ of variability in treatment with $5 \%$ exudates (Additional file 3: Figure S3).

During the early stage of the decomposition, Proteobacteria was the most enriched phylum, specifically at higher dose of exudates (Fig. 4). This was caused by a significant increase in relative abundance of Pseudomonas (at both levels of exudate addition but more pronounced at $5 \%$ level) and Burkholderia (only at $5 \%$ level of exudate addition) (Table 1). Other genus from Gammaproteobacteria, Masillia responded oppositely and its proportion in the community decreased after exudate addition. Bacteroidetes phylum was enriched during early stage of the decomposition. In more detail, Mucilaginibacter genus proportion and abundance was increasing together with level of added root exudates (Table 1). 
Table 1

Significant differences in relative abundance (\%) of bacterial genera between the control and treatments with added root exudates $(2 \%$ or $5 \%)$ at particular sampling times

\begin{tabular}{|lllllll|}
\hline Time (day) & 4 & \multicolumn{3}{c}{11} & \multicolumn{2}{c|}{25} \\
\hline Treatment (addition level) & $2 \%$ & $5 \%$ & $2 \%$ & $5 \%$ & $2 \%$ & $5 \%$ \\
\hline Acidobacteria & & & & & & \\
\hline Bryocella & - & - & - & 1.43 & 0.28 & 0.66 \\
\hline Candidatus_Solibacter & - & - & 0.03 & - & 0.08 & 0.96 \\
\hline Granulicella & - & - & 0.02 & - & -2.71 & -4.4 \\
\hline Telmatobacter & - & -0.3 & - & - & -1.2 & -1.13 \\
\hline Gammaproteobacteria & & & & & & \\
\hline Burkholderia & - & 20.55 & - & - & - & 0.08 \\
\hline Legionella & - & - & 1.16 & 4.42 & 0.11 & 0.29 \\
\hline Massilia & -5.63 & -7.41 & - & -0.38 & - & - \\
\hline Pseudomonas & 5.56 & 10.95 & 0.33 & 0.49 & 0.02 & 0.02 \\
\hline Bacteroidetes & & & & & & \\
\hline Mucilaginibacter & 0.79 & 2.67 & 0.21 & 0.51 & 0.1 & 0.08 \\
\hline
\end{tabular}

At day 11, Proteobacteria were still enriched and Bacteriodetes and Acidobacteria phyla also increased their relative abundance in amended samples compare to control

(Fig. 4). This was mainly attributed to Legionella and Pseudomonas (Proteobacteria) and Bryocella (Acidobacteriaceae (Subgroup 1)), which were the most enriched genera in this stage of decomposition (Table 1).

After 25 days of incubation, microbial communities of amended samples had significantly lower proportions of Acidobacteria as compared to control. However, looking deeper into the taxonomy of Acidobacteria, there were large differences in the response of specific genera. Granulicella and Telmatobacter (both belonging to Acidobacteriaceae (Subgroup 1)) decreased their proportion in the community, while Candidatus Solibacter (Acidobacteria, Subgroup 3) and Bryocella (Acidobacteriaceae (Subgroup 1)) were enriched (Table 1; for more details about bacterial and fungal community see Additional file 4: Table S1 and Additional file 5: Table S2, respectively).

We investigated in the detail a response of microbial community to $5 \%$ addition with the exudate $\mathrm{C} / \mathrm{N}$ ratio 50 (Table S3), because this addition induced the most pronounced changes in bacterial community 
and was connected with the largest positive PE (Fig. 2). In the early stage of decomposition, Methylocella was enriched in the treatment with high exudate $\mathrm{C} / \mathrm{N}$ ratio up to $0.18 \%$ as compared to both $\mathrm{C} / \mathrm{N}$ ratio 7 and 25 ( $\mathrm{p}<0.05 ;$ Tab. S3). At day 11 , the $\mathrm{C} / \mathrm{N}$ ratio 50 had the highest increase of fungal genus Rhodotorula by $25.1 \%$ as compared to $\mathrm{C} / \mathrm{N}$ ratio $7(\mathrm{p}<0.05)$ and was enriched by $0.4 \%$ with Methylobacterium as compared to both $\mathrm{C} / \mathrm{N}$ ratio 7 and 25 . A significant positive response on exudates with $\mathrm{C} / \mathrm{N}$ ratio 50 was found also for Candidatus Solibacter as compared to $\mathrm{C} / \mathrm{N}$ ratio 7 and for Legionella and Byssovorax as compared to $\mathrm{C} / \mathrm{N}$ ratio 25 by $0.5 \%, 1.5 \%$ and $0.3 \%$, respectively (Additional file 6: Table S3).

\section{Temporal changes of functional potential of prokaryotic community}

Average 16SrRNA gene copy number per genome (ACN) can be used as the proxy for characterizing the ror K-strategy nature of bacterial community, as higher average ACN shows the higher proportion of the copiotrophic taxa. High level of exudates addition significantly rise ACN in the bacterial community till the day 4 (Fig. 5), which indicates increased abundance of r-strategic species. Till 11 days, the ACN decreased, but was still significantly higher than control $(p<0.05)$, while later on ACN did not differ among treatments. The ACN was negatively correlated with SRP concentration and positively correlated with respiration rate $(r=-0.71$ and $r=0.69$, respectively; $p<0.05)$ at day 4 of the incubation. However, these correlations disappeared at day 11 and later.

Bacterial community contained 4096 zOTU, from which $37 \%$ was assigned to metabolic or other ecologically relevant functions using FAPROTAX bioinformatic pipeline. The main metabolic guilds showed distinct temporal behavior after $2 \%$ and $5 \%$ exudate addition (Fig. 6 ). At day 4 , the $5 \%$ level of exudates addition significantly increased the proportion of chemoheterotrophic prokaryotes while the proportion of anaerobes including fermenting bacteria decreased. This trend was almost identical for all exudates $\mathrm{C} / \mathrm{N}$ ratios. Contrary, the day 11 was characteristic by a diminished chemoheterotrophy and a relative increase of chemolitotrophs across all exudate $\mathrm{C} / \mathrm{N}$ ratios, from which $90 \%$ were ammonia oxidizers. Similar changes occurred also after $2 \%$ level of exudate addition but these changes were mostly not significant. The $5 \%$ level of exudates addition also increased the proportion of anaerobes at the end of incubation ( $25^{\text {th }}$ day) at all $\mathrm{C} / \mathrm{N}$ ratios but specifically at the highest $\mathrm{C} / \mathrm{N}$ ratio (for more detailed statistical analysis of functional potential of prokaryotic community see Additional file 7 Table S4).

PICRUSt, another functional analysis, revealed that bacteria capable to decompose complex organic matter were significantly enriched during first four days in all treatments (including control). The enrichment was more pronounced after the $5 \%$ level of exudates addition, where these bacteria formed $6.5 \%$ OUT compared to $5.8 \%$ in both control and low level of exudate addition $(\mathrm{p}<0.001)$. Afterwards, both amended treatments remained enriched by the bacteria able to decompose complex material compared to control by ca $0.4 \%$ in 11 days (control $-4.7 \%$ ) and by ca $0.2 \%$ at the end of incubation (control $-5.2 \%$ ). 


\section{Discussion}

\section{Priming effect was influenced by quantity and $\mathrm{C} / \mathrm{N}$ ratio of added exudates}

The resulting priming effect on peatland DOC decomposition was primarily affected by the exudate input: the low level of root exudatesto peatland water resulted in either a slightly negative (for $\mathrm{C} / \mathrm{N}$ ratio 7 ) or no $\mathrm{PE}$ (for $\mathrm{C} / \mathrm{N}$ ratio 25 and 50 ) on pre-existing peatland DOC (Fig 1c), whereas the higher level of root exudates a positive PEincreasing exudate $\mathrm{C} / \mathrm{N}$ ratio from 7 to 50 (Fig $1 \mathrm{~d}$ ). Our results are in line with findings of [17] who found that low level of $C$ addition lead to a negative or no PE during 7 week incubation, while the high level of $\mathrm{C}$ addition induced positive priming and of [40], who observed an increasing $\mathrm{PE}$ with an increasing $\mathrm{C} / \mathrm{N}$ ratio of crop residues added to the soil.

\section{Decomposition and microbial community dynamics after root exudates input}

The priming effect was a dynamic process, closely related to the growth and succession of the present microbial community. The growth and the composition of the microbial communities in the samples were primarily controlled by the level of root exudates addition. While the low level of exudate addition enabled only limited microbial growth, the high exudate addition level resulted in a significant temporary increase in microbial, especially bacterial abundance. Therefore, the related growth nutrient demand and a capacity to produce extracellular enzymes and decompose the native DOC were larger after the high exudate input. The rapidly growing communities first took up the available nutrients, as shown by a pronounced depletion of ammonia and SRP from the incubated solutions. Later, the decomposition of native DOC increased in samples enriched by high exudate level as a result of co-metabolism and/or a targeted nutrient mining $[21,23]$.

The two distinct phases of exudate and DOC utilization were connected with a significant successional development of bacterial community size (Fig. 4) and composition, similarly as observed by [18]. The highest shift in the bacterial community composition occurred between $4^{\text {th }}$ and $11^{\text {th }}$ day (Fig. 6). We compare the two stages (early stage and late stage) varying in exudate and DOC decomposition, microbial abundance and community composition in more detail below.

\section{The early stage - a preferential use of exudates and negative PE}

The early stage of incubation immediately following the exudate addition (till day 4) was characteristic by a preferential use of the added compounds by the microbial community, resulting in a strong negative PE (Fig. 1). The exudate addition induced transitional bacterial growth connected with a rapid uptake of 
SRP and inorganic $\mathrm{N}$ from the solution and subsequent depletion of simple exudates from the solution. The r-strategic bacteria, mainly the representatives of Gammaproteobacteria and Bacteriodetes, enhanced their relative abundance within the community. These are known as copiotrophic bacteria with a rapid turnover [41], which are often stimulated by the presence of labile substrates like root exudates [42-44]. The highest enrichment was observed for Burkholderia, Pseudomonas (Proteobacteria) and Mucilaginibacter (Bacteroidetes), which are typical by their large metabolic versatility $[45,46]$.

Pseudomonas and Burkholderia are able to degrade complex aromatic compounds including lignin and other phenolics [47] and Pseudomonas also produce chitinolytic enzymes [48]. Pseudomonas belongs among the most efficient phosphate solubilizers due to production of organic acids [49] and can facilitate iron uptake of plants by producing pyoverdines [50]. Therefore, Pseudomonas could facilitate nutrients (mainly P) uptake by plants, especially in nutrient limited environment like peatlands. Mucilaginibacter is also able to degrade complex biopolymers like cellulose [51].

In accordance with the observed community enrichment by the efficient decomposers, our functional analysis showed a large potential of the present bacterial community to degrade complex organic compounds, including cellulose and aromatics. We therefore suggest that this community dominated by the r-strategic taxa with a large decomposition potential largely contributes to the positive $\mathrm{PE}$, which was observed at $11^{\text {th }}$ day (Fig. 2). This partly contradicts a classical understanding of the PE mechanism, which suggests that the main role in production of exoenzymes degrading complex SOC is played by Kstrategists, which follow in the succession, when the r-strategic community dies after a depletion of simple substrates [27].

Because the largest PE occurred in the samples enriched by the high level of exudates (5\% of pre-existing DOC) of the $\mathrm{C} / \mathrm{N}$ ratio of 50 , we focused on the specific bacterial taxa responding significantly under this treatment. We found that a facultative methanotroph Methylocella was enriched under these conditions (Table S3). Methylocella can grow on various simple $\mathrm{C}$ compounds including acetate, succinate, malate etc. [52]. It is able to fix atmospheric $\mathrm{N}_{2}$ [53,54], which may favour Methylocella species under $\mathrm{N}$ limiting conditions. Similarly, [55] found another methylotrophic and putative $\mathrm{N}_{2}$ fixing bacteria Methylobacterium enriched in treatments with high $\mathrm{C} / \mathrm{N}$ ratio. Additionally, methanotrophs produce a unique enzyme methane monooxygenase (mmo). Monooxygenases produced by other bacteria are known to degrade aromatics. It was thus suggested that methanotrophs might also contribute to their degradation [56], although there has been no evidence that either Methylocella or Methylobacterium are capable of complex aromatic compounds degradation up to date [57].

\section{The later stage of the incubation - shift from r- to K-strategy after exudate depletion}

Exudate depletion from the solution occurred before day 4 as indicated by a sharp decrease in microbial respiration rates (Fig. 1) and was followed by a decline of bacterial abundance between days 4 and 11 mainly. Consequently, the large original community of r-strategists was replaced by a new, smaller 
community composed of different groups of bacteria mostly belonging to Alphaproteobacteria and Acidobacteria. Acidobacteria in general are reported as the dominant microbial group in peatlands because they prefer low pH and oligotrophic conditions [58,59]. Members of Acidobacteria are also efficient cellulose decomposers $[45,51,60,61]$ and their high abundance in microbial community may drive the litter degradation in acidic Sphagnum peat [62]. From Acidobacteria, the Bryocella species, enriched specifically at day 11 , was shown to have high enzymatic activity [45] and thus may contribute to the significant positive PE observed at day 11 (Fig. 2). Another Acidobacteria, Candidatus Solibacter, was one of a few genera enriched under high $\mathrm{C} / \mathrm{N}$ ratio at the end of the incubation (day 25). This genus is capable of cellulose, hemicellulose and chitin degradation and may contribute to the DOC decomposition in the later stage of incubation. We thus suggest that the enhanced DOC decomposition and the observed positive PE at days 11 and 25 can be attributed to a mixture of enzymes produced by both the rstrategists activated after exudate addition and by later incoming K-strategists. In the samples amended by the high level of exudates with $\mathrm{C} / \mathrm{N}$ ratio of 50 , where the microbial growth was the most dynamic, the community was further enriched in anaerobes in the late stage of the incubation ( $25^{\text {th }}$ day). This may relate to the largest die back of the community grown on exudates and a consequent release of simple compounds during its necromass decomposition [63].

Except of the above mentioned heterotrophic bacteria, the community characteristic for the later stage of incubation, specifically for the $11^{\text {th }}$ day, was further enriched in chemolithotrophic ammonia oxidizers (Fig. 9). Their larger presence was likely enabled by a depletion of simple organic substrates and a dieback of fast-growing bacteria, which could otherwise over compete these slow growing microbes. Moreover, the biomass die-back and the DOC decomposition enhanced the availability of $\mathrm{NH}_{4}{ }^{+}$, which is used in their energetic metabolism.

\section{Upscale to ecosystem level (a potential role of plant exudates in stimulation of peatland DOC decomposition in situ)}

In the study [26] was estimated that root exudates of peatland vascular plants, which were easily degradable, could contribute from $1 \%$ up to $5 \%$ to the pre-existing peatland DOC in situ. Our results evoke that a lower input of root exudates, achieving around $2 \%$ of DOC has a significant effect on composition of rhizosphere microbial community, but is insufficient to induce a significant positive PE on recalcitrant peatland DOC. However, when the exudate input increases to the level of $5 \%$ of the present DOC, it may induce a transient positive priming effect lasting several days. With exudates poor for $\mathrm{N}(\mathrm{C} / \mathrm{N}$ ratio of 50$)$, the induced positive priming may persist for more than two weeks and result in an enhanced decomposition of the pre-existing DOC. According to [26], the situation, when the exudation input is high enough, occurs at the top of the season especially in the presence of graminoid species such as Eriophorum vaginatum. However, the exudates at that time were relatively rich in $\mathrm{N}$, therefore likely not causing significant peatland DOC losses. We suggest that the plants may rather benefit from the changes

Page $11 / 30$ 
in the composition of microbial community, which the exudates induce in their rhizosphere. According to our results, root exudates input supports a growth of r-strategic species, which are able to immobilize high amounts of nutrients in their biomass, keep them in the vicinity of plant roots, protect them from losses with the leaching DOC and potentially release them for the plant uptake during their fast turnover. The rhizosphere community is enriched in species like Pseudomonas, which can mobilize $\mathrm{P}$ and others (e.g. Burkholderia and Mucilaginibacter) with high metabolic potential. The presence of microbial communities able to keep nutrients in the rhizosphere of peatland vascular plants is further supported by our previous results from the field. In [64] we showed that the soil microbial biomass associated with Eriophorum vaginatum and Vaccinium myrtillus immobilizes large amounts of $\mathrm{N}$ and $\mathrm{P}$ present in the system. Additionally, the association of ericaceous shrubs with mycorrhizal fungi increases $P$ mobilization and increases its availability to the plants (Read et al. 2004).

Differently from root exudates of vascular plants, Sphagnum "exudates" is not expected to cause a significant positive priming effect on DOC decomposition. Although the Sphagnum-released compounds can contribute up to $20 \%$ to the peatland DOC, they are of low degradability being only around $15 \%$ [26]. We expect that these would not stimulate a growth of specific bacterial communities and their enzymatic production. Additionally, the compounds leached from Sphagnum were shown to immobilize phosphorus by its incorporation to the high molecular weight complexes and by co-precipitation with metals [65] and they are known by their antimicrobial effects [66].

In accordance with the study of [8], we suggest that an input of root exudates from vascular plants may induce a positive PE on organic matter decomposition in the peatlands, but its importance for $\mathrm{C}$ transformation and ecosystem $\mathrm{C}$ balance is likely minor under current conditions. Current level of root exudation rather helps vascular plants to keep nutrients immobilized in the microbial biomass with fast turnover in the vicinity of the roots and thus facilitates their survival in the nutrient limited environment. However, if ongoing climate changes will result in a significant spread of vascular plants over peatlands, a priming effect caused by the enhanced root exudation could lead to higher dynamics of $\mathrm{C}$ cycle in peatlands and larger $\mathrm{C}$ mineralization.

\section{Conclusions}

1/ Priming effect was affected by level of root exudates addition: Low level of root exudates addition ( $2 \%$ of total DOC) to peatland water caused negative priming effect (PE) whereas positive PE can occur with increasing level of root exudates ( $5 \%$ of total DOC). Increasing $\mathrm{C} / \mathrm{N}$ ratio from 7 to 50 enhances $\mathrm{PE}$. Growing microbial community was limited by nutrients and the $\mathrm{C}$ excess induced by the input of $\mathrm{C}$-rich exudates led to increased "microbial nutrient mining" from dissolved organic matter.

2/ Bacteria played more important role than fungi in our experiment as indicated by the extremely low ratio fungi/bacteria (lower than 0.005 ). After root exudates addition, r-strategic bacteria abundances increased and their growth was connected with an increased uptake of SRP and ammonium $\mathrm{N}$ from peatland water. High level of added root exudates stimulated growth of microbial functional groups with 
a potential to decompose complex compounds. Therefore, our experiment indicates that r-strategic bacteria (mainly Gammaproteobacteria) importantly contribute to a positive PE on peatland DOC decomposition. The positive PE found in the treatments with high level of exudates addition, could be caused by both the enzymes produced by K-strategic bacteria and by the enzymes produced by r-strategic bacteria during their growth on simple exudates.

3/ Detailed analysis of microbial community revealed several genera with high enzymatic activity, which could cause or contribute to positive PE on peatland DOC; Burkholderia, Pseudomonas and Mucilaginibacter stimulated by root exudates input were the most important groups of r-strategic bacteria; later followed by K-strategists Bryocella and Candidatus Solibacter.

\section{Methods}

\section{Peatland water collection and preparation}

Peatland water originated from a spruce swamp forest located in the Šumava Mountains southwest Czech Republic $\left(49^{\circ} 1^{\prime} 28.04^{\prime \prime} \mathrm{N}, 13^{\circ} 32^{\prime} 32.14^{\prime \prime} \mathrm{E}\right)$ and it was collected in October 2015. The water was filtered through the low-protein-binding Express PLUS Polyethersulfone membrane (GPWP) with a 0.22 $\mu \mathrm{m}$ pore size (Merck Millipore Ltd., Ireland). The filtrate was analysed for dissolved organic C (DOC) (60 $\mathrm{mg} \mathrm{L}^{-1}$ ) on a LiquiTOC II (Elementar, Germany) and for $\mathrm{pH}(\mathrm{pH}=4)$.

\section{Experimental design of incubation}

Peatland water was incubated in $120 \mathrm{ml}$ glass NTS vials. The control treatment consisted of the $75 \mathrm{ml}$ of the filtrated peatland water with the final DOC concentration of $60 \mathrm{mg} \mathrm{C} \mathrm{L}^{-1}$. In experimental treatments, the peatland water was enriched by a mixture of simple organic compounds with different molar $\mathrm{C} / \mathrm{N}$ ratio simulating root exudates. The basic mixture of artificial root exudates with the molar $\mathrm{C} / \mathrm{N}$ ratio of 50:1 consisted of acetic acid, glucose and glutamic acid $\left({ }^{13} \mathrm{C}\right.$ labelled compounds, 99 at. $\%$ of ${ }^{13} \mathrm{C}$, Sigma Aldrich), which contributed to the total $C$ in the mixture by $75 \%, 15 \%$ and $10 \%$, respectively $[26,67,68]$. The molar $\mathrm{C} / \mathrm{N}$ ratios of 25:1 and 7:1 were adjusted by an addition of ammonium nitrate to the basic mixture of organics. The artificial root exudates were added to the peatland water in two concentrations representing $2 \%$ and $5 \%$ of the recalcitrant DOC concentration in four replicates. Then the samples were inoculated by $0.5 \mathrm{ml}$ of unfiltered supernatant prepared from the peat sampled at the same locality as the peatland water $\left(10 \mathrm{~g}\right.$ of peat shaken in $100 \mathrm{ml}$ of distilled water for $1 \mathrm{~h}$ at $20^{\circ} \mathrm{C}$, and centrifuged at $1000 \mathrm{~g}$ for 5 minutes). After inoculation the vials were air-tightly closed with rubber stoppers and incubated on the roll-and-roll shaker at $20^{\circ} \mathrm{C}$ for 25 days.

At time $0,4,11$ and 25 days after start of the incubation the solution was taken from each sample, filtered through the low-protein-binding Express PLUS Polyethersulfone membrane (GPWP) with a $0.22 \mu \mathrm{m}$ pore size (Merck Millipore Ltd., Ireland)) and immediately analysed for soluble reactive $\mathrm{P}$ (SRP), ammonium $\mathrm{N}$ 
and nitrate N collorimetrically on flow injection analyser (FIA Lachat QC8500, Lachat Instruments, USA). The filtrate was analysed for dissolved organic C (DOC) and total dissolved nitrogen (TDN) on a LiquiTOC II (Elementar, Germany).

\section{Respiratory $\mathrm{C}$ losses from the samples and priming effect}

The $\mathrm{CO}_{2}$ and $\mathrm{O}_{2}$ concentration in the headspace of each flask was measured at $1,2,3,4,7,11,18$ and 25 days of incubation using a HP 6850 gas chromatograph (Agilent, USA). After each measurement, the flasks were opened, ventilated and closed again. The $\mathrm{CO}_{2}$ data were used to calculate respiration rates and cumulative respiratory losses for each treatment, which were used as a proxy for decomposition losses.

At days 1, 4, 11 and 25, isotopic composition of the evolved $\mathrm{CO}_{2}$ was analysed by Gasbench II (Finnigan, Germany) connected with IRMS Delta X Plus (Finnigen, Germany). To calculate the amount of $\mathrm{CO}_{2}$ derived from exudates and pre-existing DOC, the following mass balance equations based on atom \% were used:

$$
C_{\mathrm{T}} \delta_{\mathrm{T}}=C_{\mathrm{EX}} \delta_{\mathrm{EX}}+C_{\mathrm{DOC}} \delta_{\mathrm{DOC}}
$$

where $C_{\mathrm{T}}\left(C_{\mathrm{T}}=C_{\mathrm{EX}}+C_{\mathrm{DOC}}\right)$ is the total amount of $\mathrm{CO}_{2}$ during the considered time interval, $\delta_{\mathrm{T}}$ is the corresponding isotopic composition, $C_{\mathrm{EX}}$ is the amount of $\mathrm{CO}_{2}$ derived from the added exudates, $\delta_{\mathrm{EX}}$ is its isotopic composition in the exudates, $C_{\mathrm{DOC}}$ is the amount of $\mathrm{CO}_{2}$ derived from DOC and $\delta_{\mathrm{DOC}}$ is its isotopic composition. The primed DOC-derived $\mathrm{CO}_{2}$ is the difference between the $C_{\mathrm{DOC}}$ of exudateamended samples and $\mathrm{C}-\mathrm{CO}_{2}$ efflux from control samples $\left(C_{\text {control }}\right)$. The extent of PE was expressed as relative (\%) to respiration rate of control at particular sampling time.

$$
\mathrm{PE}(\%)=100 \times\left(\mathrm{C}_{\mathrm{DOC}} \text { in exudate-amended samples }-\mathrm{C}_{\text {control }}\right) / \mathrm{C}_{\text {control }}
$$

\section{Nucleic acid extraction and quantification}

$10 \mathrm{ml}$ of peatland water were filtered through the low-protein-binding Express PLUS Polyethersulfone membrane (MILLGPWP) with a $0.22 \mu \mathrm{m}$ pore size (Merck Millipore Ltd., Ireland). Filters were kept frozen until nucleic acid (DNA) extraction. Filters were cut into the small pieces to fit bead-beating tube. DNA was extracted from the filters according to modified bead-beating protocol [69]. Total DNA was quantified fluorometrically using Quantus fluorometer (Promega, USA) with Quantus DNA Start-Up Kit. Quality of DNA was also verified by agarose gel electrophoresis.

\section{DNA sequencing and microbial community analyses}


The aliquots of DNA extracts were sent to SEQme company (Czech republic) for the preparation of a library and sequencing using HiSeq2500 platform. The Earth Microbiome Project (EMP) protocol was used for library preparation with modified universal primers 515FB/806RB [70] and ITS1F/ITS2 [71] for prokaryotic 16S rDNA and fungal ITS1 amplicons, respectively. Bacterial 16SrDNA raw pair-end reads (150 bp) were joined and quality filtered using USEARCH v. 10.0.240 to obtain reads of approx. 250bp length [72]. The fungal ITS1 region was extracted from reads using ITSx algorithm [73]. Both 16S and ITS1 amplicons were trimmed to equal lengths. Bacterial and fungal unique reads were grouped to zeroradius OTUS (zOTUs) using an UNOISE 3.0 algorithm, which includes also the removal of potential chimeric sequences [72]. Taxonomic assignment of each bacterial and fungal zOTU was done using blast algorithm (e-value $=0.001$ ) and curated ARB Silva 132 database [74] and UNITE v 7.2 [75]. Raw sequencing data were deposited in European Nucleotide Archive (ENA) under the study ID PRJEB29666.

\section{Quantification of prokaryotic and eukaryotic microbial community}

Quantification of bacterialand fungal SSU rRNA genes was performed using the FastStart SybrGREEN Roche ${ }^{\circledR}$ Supermix and Step One system (Life Technologies, USA). Each reaction mixture $(20 \mu \mathrm{l})$ contained $2 \mu \mathrm{l}$ DNA template ( 1-2 ng DNA), $1 \mu \mathrm{l}$ each primer ( $0.5 \mathrm{pmol} \mu \mathrm{l}-1$ each, final concentration), 6 $\mu \mathrm{ldH} 2 \mathrm{O}, 10 \mu \mathrm{l}$ FastStart SybrGREEN Roche ${ }^{\circledR}$ Supermix (Roche, France) and $1 \mu \mathrm{l} \mathrm{BSA} \mathrm{(Fermentas,} 20 \mathrm{mg}$ $\left.\mu \mathrm{l}^{-1}\right)$. Initial denaturation $\left(3 \mathrm{~min}, 95^{\circ} \mathrm{C}\right.$ ) was followed by 30 cycles of $30 \mathrm{~s}$ at $95^{\circ} \mathrm{C}, 30 \mathrm{~s}$ at $62^{\circ} \mathrm{C}$ (bacteria), $15 \mathrm{~s}$ at $72^{\circ} \mathrm{C}$, and completed by fluorescence data acquisition at $80^{\circ} \mathrm{C}$ used for target quantification. Product specificity was confirmed by melting point analysis $\left(52^{\circ} \mathrm{C}\right.$ to $95^{\circ} \mathrm{C}$ with a plate read every $\left.0.5^{\circ} \mathrm{C}\right)$ and amplicon size was verified with agarose gel electrophoresis. Bacterial DNA standards consisted of a dilution series (ranging from $10^{1}$ to $10^{9}$ gene copies $\mu^{-1}$ ) of a known amount of purified PCR product obtained from genomic Escherichia coli ATCC 9637 DNA by using the SSU gene-specific primers $341 F / 534 R$ [76]. $R^{2}$ values for the standard curves were $>0.99$. Slope values were $>3.37$ giving an estimated amplification efficiency of $>93 \%$. The qPCR conditions for fungal quantification were as follows: initial denaturation $\left(10 \mathrm{~min}, 95^{\circ} \mathrm{C}\right.$ ) followed by 40 cycles of $1 \mathrm{~min}$ at $95^{\circ} \mathrm{C}, 1 \mathrm{~min}$ at $56^{\circ} \mathrm{C}, 1 \mathrm{~min}$ at $72^{\circ} \mathrm{C}$, and completed by fluorescence data acquisition at $72^{\circ} \mathrm{C}$ used for target quantification. Fungal DNA standards consisted of a dilution series (ranging from $10^{1}$ to $10^{7}$ gene copies $\mu l^{-1}$ ) of a known amount of purified PCR product obtained from genomic Aspergillus niger DNA by using the SSU gene-specific primers nu-SSU-0817-5' and nu-SSU1196-3' [77]. $\mathrm{R}^{2}$ values for the fungal standard curves were $>0.99$. The slope was between -3.32 to -3.5 giving estimated amplification efficiency between 97 and 91\%, respectively. Detection limits for the various assays (i.e. lowest standard concentration that is significantly different from the non-template controls) were less than 100 gene copies for each of the genes per assay. Samples, standards and non-template controls were run in duplicates. 


\section{Analyses of metabolic potential of the prokaryotic community}

Two independent pipelines (PICRUSt, FAPROTAX) were used for in-silico prediction of the functional potential of the prokaryotic community. For PICRUSt [78] and FAPROTAX [39] analyses the rarified OTU tables to 2000 sequences generated by Qiime 1.9.1 were used with taxonomic classification based on GreenGenes database ver. 13.05. In general, the PICRUSt pipeline first normalized each OTU abundances by small ribosomal subunit gene (SSU) copy variation in bacterial genomes based on the most similar taxa. The resulting normalized table was then used for OTU functional annotation using known bacterial and archaeal genomes [78]. From the normalized OTU table we were additionally able to calculate community average genome SSU copy number (ACN) in each sample [79]. The ACN was calculated from the raw and normalized OUT table ( $1^{\text {st }}$ step in PICRUSt pipeline). SSU gene copies range from 1 to 15 in microbial genomes. Copiotrophic microbes are assumed to have more SSU gene copies in genome, therefore the higher average $\mathrm{ACN}$ shows the higher proportion of the copiotrophic taxa in the microbial community.

\section{Statistical analyses}

The effects of exudates additions, their $\mathrm{C} / \mathrm{N}$ ratios and time on each parameter (respiration rate, priming effect, nutrient concentrations, bacterial and fungal abundance) were tested by full-factorial repeatedmeasures ANOVA (Statistica 12, Dell, USA) followed by post hoc comparison (unequal N HSD test). The significant differences (Welchs t-test, two-sided, Bonferroni correction) of phyla and genera between different treatments and control were analysed in STAMP v2.1.3 [80].

\section{Supplementary Information}

Additional file 1: Figure $\mathrm{S} 1$ Nitrate $\mathrm{N}\left(\mathrm{NO}_{3}\right)$ concentration in control samples and samples amended by artificial exudates with different $\mathrm{C} / \mathrm{N}$ ratios $\mathrm{A}$ in concentration of $2 \%$ of total $\mathrm{DOC}$ and $\mathrm{B} /$ in concentration of $5 \%$ of total DOC during 25 days incubation (means, \pm standard deviations, $n=4$ )

Additional file 2: Figure S2 Fungi/bacteria ratio in control samples and samples amended by artificial exudates with different $\mathrm{C} / \mathrm{N}$ ratios $\mathrm{A}$ in concentration of $2 \%$ of total $\mathrm{DOC}$ and $\mathrm{B} /$ in concentration of $5 \%$ of total DOC during 25 days incubation (means, \pm standard deviations, $n=4$ )

Additional file 3: Figure S3 The temporal changes of bacterial community composition $\mathbf{A}$ in control and $\mathrm{B} /$ in samples amended by artificial exudates with different $\mathrm{C} / \mathrm{N}$ ratios in concentration of $2 \%$ of total DOC and $\mathrm{C} /$ in concentration of $5 \%$ of total DOC during 25 days incubation

Additional file 4: Table $\mathbf{S} 1$ Changes in bacterial community after artificial root exudates addition ( $2 \%$ or $5 \%$ of total DOC). 
Additional file 5: Table S2 Changes in fungal community after artificial root exudates addition ( $2 \%$ or $5 \%$ of total DOC).

Additional file 6: Table S3 Changes in microbial community after addition of artificial root exudates with different $\mathrm{C} / \mathrm{N}$ ratio $(7,25,50)$

Additional file 7: Table S4 Statistical analysis of functional potential of prokaryotic community ( $p$-value difference between control and treatment; t-test)

\section{Declarations}

\section{Acknowledgements}

We thank Ondřej Žampach, Daniel Vaněk, Kateřina Kučerová and Hana Petrásková for technical support and chemical analyses and Keith Raymond Edwards for language corrections.

\section{Authors' contributions}

$\mathrm{JM}$, EK and TP conceived and designed the study. JM, JB, EK and TP contributed to the data acquisition and carried out the data analysis. JM drafted the manuscript, and all authors edited the manuscript. All authors read and approved the final manuscript.

\section{Availability of data and materials}

Raw sequence data were deposited in European Nucleotide Archive (ENA) under the accession number PRJEB36145.

\section{Funding}

This work was supported by Czech Science Foundation grant no. 18-19561S. The article was further supported from MEYS; projects [LM2015075] and [EF16_013/0001782] - SoWa Ecosystems Research.

\section{Ethics approval and consent to participate}

Not applicable.

\section{Consent for publication}

Not applicable.

\section{Competing interests}

The authors declare that they have no competing interests. 


\section{References}

1. Tfaily MM, Hamdan R, Corbett JE, Chanton JP, Glaser PH, Cooper WT. Investigating dissolved organic matter decomposition in northern peatlands using complimentary analytical techniques. Geochim Cosmochim Acta. 2013;112:116-29.

2. Clark JM, Lane SN, Chapman PJ, Adamson JK. Link between DOC in near surface peat and stream water in an upland catchment. Sci Total Environ. 2008;404:308-15.

3. Thacker SA, Tipping E, Gondar D, Baker A. Functional properties of DOM in a stream draining blanket peat. Sci Total Environ. 2008;407:566-73.

4. Jones DL, Nguyen C, Finlay RD. Carbon flow in the rhizosphere: Carbon trading at the soil-root interface. Plant Soil. 2009;321:5-33.

5. van Huissteden J, van den Bos R, Marticorena Alvarez I. Modelling the effect of water-table management on $\mathrm{CO}_{2}$ and $\mathrm{CH}_{4}$ fluxes from peat soils. Netherlands $\mathrm{J}$ Geosci. 2006;85:3-18.

6. Lu Y, Conrad R. In Situ Stable Isotope Probing of Methanogenic Archaea in the Rice Rhizosphere. Science. 2005;309:1088-91.

7. Hamer U, Marschner B. Priming effects of sugars, amino acids, organic acids, and catechol on the mineralization of lignin and peat. J Plant Nutr Soil Sci. 2002;165:261-8.

8. Basiliko N, Stewart H, Roulet NT, Moore TR. Do Root Exudates Enhance Peat Decomposition? Geomicrobiol J. 2012;29:374-8.

9. Buttler A, Robroek BJM, Laggoun-Défarge F, Jassey VEJ, Pochelon C, Bernard G, et al. Experimental warming interacts with soil moisture to discriminate plant responses in an ombrotrophic peatland. $\mathrm{J}$ Veg Sci. 2015;26:964-74.

10. Weltzin JF, Pastor J, Harth C, Bridgham SD, Updegraff K, Chapin CT. Response of Bog and Fen Plant Communities to Warming and Water-Table Manipulations Published by: Ecological Society of America RESPONSE OF BOG AND FEN PLANT COMMUNITIES TO WARMING AND WATER-TABLE MANIPULATIONS. Ecology [Internet]. 2009;81:3464-78. Available from:

https://esajournals.onlinelibrary.wiley.com/doi/full/10.1890/0012-

9658\%282000\%29081\%5B3464\%3AROBAFP\%5D2.0.CO\%3B2

11. Dieleman CM, Branfireun BA, Mclaughlin JW, Lindo Z. Climate change drives a shift in peatland ecosystem plant community: Implications for ecosystem function and stability. Glob Chang Biol. 2015;21:388-95.

12. Frolking S, Roulet NT, Moore TR, Lafleur PM, Bubier JL, Crill PM. Modeling seasonal to annual carbon balance of Mer Bleue Bog. Global Biogeochem Cycles. 2002;16:1-21.

13. Zhu B, Gutknecht JLM, Herman DJ, Keck DC, Firestone MK, Cheng W. Soil Biology \& Biochemistry Rhizosphere priming effects on soil carbon and nitrogen mineralization. Soil Biol Biochem. 2014;76:183-92.

14. Hotchkiss ER, Hall RO, Baker MA, Rosi-Marshall EJ, Tank JL. Modeling priming effects on microbial consumption of dissolved organic carbon in rivers. J Geophys Res Biogeosciences. 2014;119:982- 
95.

15. Blagodatskaya E, Kuzyakov Y. Mechanisms of real and apparent priming effects and their dependence on soil microbial biomass and community structure: Critical review. Biol. Fertil. Soils. 2008;45:115-31.

16. Guenet, B., Danger, M., Abbadie, L., Lacroix G. Priming effect: bridging the gap between terrestrial and aquatic ecology. Ecology. 2010;91:2850-61.

17. Liu XA, Jan K, Groenigen V, Dijkstra P, Hungate BA. Increased plant uptake of native soil nitrogen following fertilizer addition - not a priming effect? Appl Soil Ecol. 2017;114:105-10.

18. Shi S, Richardson AE, O'Callaghan M, Deangelis KM, Jones EE, Stewart A, et al. Effects of selected root exudate components on soil bacterial communities. FEMS Microbiol Ecol. 2011;77:600-10.

19. Grayston SJ, Vaughan D, Jones D. Rhizosphere carbon flow in trees, in comparison with annual plants: the importance of root exudation and its impact on microbial activity and nutrient availability. Appl Soil Ecol. 1996;5:29-56.

20. Wardle DA, Greenfield LG. Release of mineral nitrogen from plant root nodules. Soil Biol Biochem. 1991;23:827-32.

21. Chen R, Senbayram M, Blagodatsky S, Myachina O, Dittert K, Lin X, et al. Soil C and N availability determine the priming effect: Microbial N mining and stoichiometric decomposition theories. Glob Chang Biol. 2014;20:2356-67.

22. Miao S, Ye R, Qiao Y, Zhu-barker X, Doane TA, Horwath WR. The solubility of carbon inputs affects the priming of soil organic matter. Plant Soil [Internet]. Plant and Soil. 2017;410:129-38. Available from: http://dx.doi.org/10.1007/s11104-016-2991-1

23. Fang Y, Nazaries L, Singh BK, Singh BP. Microbial mechanisms of carbon priming effects revealed during the interaction of crop residue and nutrient inputs in contrasting soils. Glob Chang Biol. 2018;24:2775-90.

24. Qiao N, Xu X, Hu Y, Blagodatskaya E, Liu Y. Carbon and nitrogen additions induce distinct priming effects along an organic-matter decay continuum. Nat Publ Gr [Internet]. Sci Rep. 2016;6: 19865. Available from: http://dx.doi.org/10.1038/srep19865

25. Fontaine S, Henault C, Aamor A, Bdioui N, Bloor JMG, Maire V, et al. Fungi mediate long term sequestration of carbon and nitrogen in soil through their priming effect. Soil Biol Biochem. 2011;43:86-96.

26. Edwards KR, Kaštovská E, Borovec J, Šantrůčková H, Picek T. Species effects and seasonal trends on plant efflux quantity and quality in a spruce swamp forest. Plant Soil. 2018;426:179-96.

27. Kuzyakov Y. Priming effects: Interactions between living and dead organic matter. Soil Biol Biochem. 2010;42:1363-71.

28. Wild B, Schnecker J, Eloy RJ, Barsukov P, Lashchinskiy N, Mikutta R, et al. Input of easily available organic $\mathrm{C}$ and $\mathrm{N}$ stimulates microbial decomposition of soil organic matter in arctic permafrost soil. Soil Biol Biochem. 2014;75:143-51. 
29. Makino W, Cotner JB, Sterner RW, Elser JJ. Are bacteria more like plants or animals? Growth rate and resource dependence of bacterial C: N: P stoichiometry. Funct Ecol. 2003;17:121-30.

30. Elser JJ, Dobberfubl DR, Mackay NA, Schampel JH. Organism size, life history, and N: P stoichiometry toward a unified view of cellular and ecosystem processes. Bioscience. 1996;46:67484.

31. Allison SD, Wallenstein MD, Bradford MA. Soil-carbon response to warming dependent on microbial physiology. Nat Geosci. 2010;3:336-40.

32. Schimel JP, Schaeffer SM. Microbial control over carbon cycling in soil. Front. Microbiol. 2012;3:111.

33. Fontaine S, Mariotti A, Abbadie L. The priming effect of organic matter: A question of microbial competition? Soil Biol Biochem. 2003;35:837-43.

34. Blagodatskaya E, Khomyakov N, Myachina O, Bogomolova I, Blagodatsky S, Kuzyakov Y. Microbial interactions affect sources of priming induced by cellulose. Soil Biol Biochem. 2014;74:39-49.

35. Garcia-pausas J, Paterson E. Microbial community abundance and structure are determinants of soil organic matter mineralisation in the presence of labile carbon. Soil Biol Biochem. 2011;43:1705-13.

36. Myers B, Webster KL, Mclaughlin JW, Basiliko N. Microbial activity across a boreal peatland nutrient gradient: The role of fungi and bacteria. Wetl Ecol Manag. 2012;20:77-88.

37. Winsborough C, Basiliko N. Fungal and bacterial activity in Northern peatlands. Geomicrobiol J. 2010;27:315-20.

38. Chroňáková A, Bárta J, Kaštovská E, Urbanová Z, Picek T. Spatial heterogeneity of belowground microbial communities linked to peatland microhabitats with different plant dominants. FEMS Microbiol Ecol. 2019;95:fiz130.

39. Louca S, Parfrey LW, Doebeli M. Decoupling function and taxonomy in the global ocean microbiome. Science. 2016;353:1272-7.

40. Wang H, Boutton TW, Xu W, Hu G, Jiang P, Bai E. Quality of fresh organic matter affects priming of soil organic matter and substrate utilization patterns of microbes. Nat Publ Gr [Internet]. Sci. Rep. 2015;5:10102. Available from: http://dx.doi.org/10.1038/srep10102

41. Fierer N, Bradford MA, Jackson RB. Toward an ecological classification of soil bacteria. Ecology. 2007;88:1354-64.

42. Buée M, de Boer W, Martin F, van Overbeek L, Jurkevitch E. The rhizosphere zoo: An overview of plantassociated communities of microorganisms, including phages, bacteria, archaea, and fungi, and of some of their structuring factors. Plant Soil. 2009;321:189-212.

43. Jenkins SN, Rushton SP, Lanyon C V, Whiteley AS, Waite IS, Brookes PC, et al. Taxon-specific responses of soil bacteria to the addition of low level C inputs. Soil Biol Biochem. 2010;42:1624-31.

44. Fierer N, Bradford MA, Jackson R. Toward an ecological classification of soil bacteria. Ecology. 2007;88:1354-64. 
45. Lladó S, Žifčáková L, Větrovský T, Eichlerová I, Baldrian P. Functional screening of abundant bacteria from acidic forest soil indicates the metabolic potential of acidobacteria subdivision 1 for polysaccharide decomposition. Biol. Fertil. Soils 2016;52:251-60.

46. Sun D, Meng J, Genbo E, Chen W. Microbial community structure and predicted bacterial metabolic functions in biochar pellets aged in soil after 34 months. Appl Soil Ecol. 2016;100:135-43.

47. Bandounas L, Wierckx NJP, de Winde JH, Ruijssenaars HJ. Isolation and characterization of novel bacterial strains exhibiting ligninolytic potential. BMC Biotechnol. 2011;11:94.

48. Brabcová V, Nováková $M$, Davidová $A$, Baldrian P. Dead fungal mycelium in forest soil represents a decomposition hotspot and a habitat for a specific microbial community. New Phytol. 2016;210:1369-81.

49. Rodríguez H, Fraga R. Phosphate solubilizing bacteria and their role in plant growth promotion. Biotechnol Adv. 1999;17:319-39.

50. Vansuyt G, Robin A, Briat J, Curie C, Lemanceau P, Bourgogne I De, et al. Iron Acquisition from FePyoverdine by Arabidopsis thaliana. Mol Plant Microbe Interact. 2007;20:441-7.

51. Štursová M, Žifčáková L, Leigh MB, Burgess R, Baldrian P. Cellulose utilization in forest litter and soil: Identification of bacterial and fungal decomposers. FEMS Microbiol Ecol. 2012;80:735-46.

52. Dedysh SN, Knief C, Dunfield PF. Methylocella Species Are Facultatively Methanotrophic. J Bacteriol. 2005;187:4665-70.

53. Dunfield PF, Khmelenina VN, Suzina NE, Trotsenko YA, Dedysh SN. Methylocella silvestris sp. nov., a novel methonotroph isolated from an acidic forest cambisol. Int J Syst Evol Microbiol. 2003;53:1231-9.

54. Dos Santos PC, Fang Z, Mason SW, Setubal JC, Dixon R. Distribution of nitrogen fixation and nitrogenase-like sequences amongst microbial genomes. BMC Genomics. 2012;13:1-12.

55. Raja P, Uma S, Sundaram S. Non-nodulating pink-pigmented facultative Methylobacterium sp. with a functional nifH gene. World J Microbiol Biotechnol. 2006;22:1381-4.

56. Hanson RS, Hanson TE. Methanotrophic Bacteria. Microbiol Rev.1996;60:439-71.

57. Semrau JD. Bioremediation via methanotrophy: overview of recent findings and suggestions for future research. Front Microbiol. 2011;2:1-7.

58. Lin X, Green S, Tfaily MM, Prakash O, Konstantinidis KT, Corbett JE, et al. Microbial Community Structure and Activity Linked to Contrasting Biogeochemical Gradients in Bog and Fen Environments of the Glacial. Appl Environ Microbiol. 2012;78:7023-31.

59. Amha Y, Bohne H, Alsanius B. Patterns of Fungal and Bacterial Carbon Mineralization Across Northern European Peatlands. Geomicrobiol J. 2015;32:914-23.

60. Haichar Z, Achouak W, Christen R, Heulin T, Marol C, Marais M, et al. Identification of cellulolytic bacteria in soil by stable isotope probing. Environ Microbiol. 2007;9:625-34.

61. Pankratov TA, Kirsanova LA, Kaparullina EN, Kevbrin V V, Dedysh SN. Telmatobacter bradus gen. nov., sp. nov., a cellulolytic facultative anaerobe from subdivision 1 of the Acidobacteria, and 
emended description of Acidobacterium capsulatum Kishimoto et al. 1991. Int J Syst Evol Microbiol. 2012;62:430-7.

62. Pankratov TA, Ivanova AO, Dedysh SN, Liesack W. Bacterial populations and environmental factors controlling cellulose degradation in an acidic Sphagnum peat. Environ Microbiol. 2011;13:1800-14.

63. Blagodatsky SA, Heinemeyer O, Richter J. Estimating the active and total soil microbial biomass by kinetic respiration analysis. Biol Fertil Soils. 2000;32:73-81.

64. Kaštovská E, Straková P, Edwards K, Urbanová Z, Bárta J, Mastný J, et al. Cotton-Grass and Blueberry have Opposite Effect on Peat Characteristics and Nutrient Transformation in Peatland. Ecosystems. 2018;21:443-58.

65. Mastný J, Kaštovská E, Bárta J, Chroňáková A, Borovec J, Šantrůčková H, et al. Quality of DOC produced during litter decomposition of peatland plant dominants. Soil Biol Biochem. 2018;121:221-30.

66. Painter TJ. Review Paper Lindow Man , Tollund Man and Other Peat-Bog Bodies: The Preservative and Antimicrobial Action of Sphagnan , a Reactive Glycuronoglycan with Tanning and Sequestering Properties. Carbohyd Polym. 1991;15:123-42.

67. Drake JE, Darby BA, Giasson M, Kramer MA, Phillips RP, Finzi AC. Stoichiometry constrains microbial response to root exudation- insights from a model and a field experiment in a Earth temperate System forest substrates. Biogeosciences. 2013;10:821-38.

68. Eiland F, Klamer M, Lind AM, Leth M, Bååth E. Influence of Initial C / N Ratio on Chemical and Microbial Composition during Long Term Composting of Straw. Microb Ecol. 2001;41:272-80.

69. Urich T, Lanzén A, Qi J, Huson DH, Schleper C, Schuster SC. Simultaneous assessment of soil microbial community structure and function through analysis of the meta-transcriptome. PLoS One. 2008;3:e2527.

70. Caporaso JG, Lauber CL, Walters WA, Berg-Lyons D, Lozupone CA, Turnbaugh PJ, et al. Global patterns of $16 \mathrm{~S}$ rRNA diversity at a depth of millions of sequences per sample. Proc Natl Acad Sci U S A. 2011;108:4516-22.

71. GARDES M, BRUNS TD. ITS primers with enhanced specificity for basidiomycetes - application to the identification of mycorrhizae and rusts. Mol Ecol. 1993;2:113-8.

72. Edgar RC. UPARSE: Highly accurate OTU sequences from microbial amplicon reads. Nat Methods. 2013;10:996-8.

73. Bengtsson-Palme J, Ryberg M, Hartmann M, Branco S, Wang Z, Godhe A, et al. Improved software detection and extraction of ITS1 and ITS2 from ribosomal ITS sequences of fungi and other eukaryotes for analysis of environmental sequencing data. Methods Ecol Evol. 2013;4:914-9.

74. Quast C, Pruesse E, Yilmaz P, Gerken J, Schweer T, Glo FO, et al. The SILVA ribosomal RNA gene database project: improved data processing and web-based tools. Nucleic Acids Res. 2013;41:5906.

75. Kõljalg, U., Nilsson, R.H., Abarenkov, K., Tedersoo, L., Taylor, A.F.S., Bahram, M., Bates, S.T., Bruns, T.D., Bengtsson-Palme, J., Callaghan, T.M. et al. Towards a unified paradigm for sequence-based 
identification of fungi [Internet]. Mol. Ecol. 2013;22:5271-6. Available from:

https://www.ncbi.nlm.nih.gov/pubmed/24112409

76. Muyzer G, Waal ECDE, Uitierlinden AG. Profiling of Complex Microbial Populations by Denaturing Gradient Gel Electrophoresis Analysis of Polymerase Chain Reaction-Amplified Genes Coding for $16 \mathrm{~S}$ rRNA. Appl Environ Microbiol. 1993;59:695-700.

77. Borneman J, Hartin RJ. PCR Primers That Amplify Fungal rRNA Genes from Environmental Samples. Appl Environ Microbiol. 2000;66:4356-60.

78. Langille MGI, Zaneveld J, Caporaso JG, Mcdonald D, Knights D, Reyes JA, et al. Predictive functional profiling of microbial communities using 16S rRNA marker gene sequences. Nat Biotechnol. 2013;9:814-21.

79. Thompson LR, Sanders JG, McDonald D, Amir A, Ladau J, Locey KJ, et al. A communal catalogue reveals Earth's multiscale microbial diversity. Nature. 2017;551:457-63.

80. Parks DH, Tyson GW, Hugenholtz P, Beiko RG. STAMP: statistical analysis of taxonomic and functional profiles. Bioinformatics. 2014;30:3123-4.

\section{Figures}



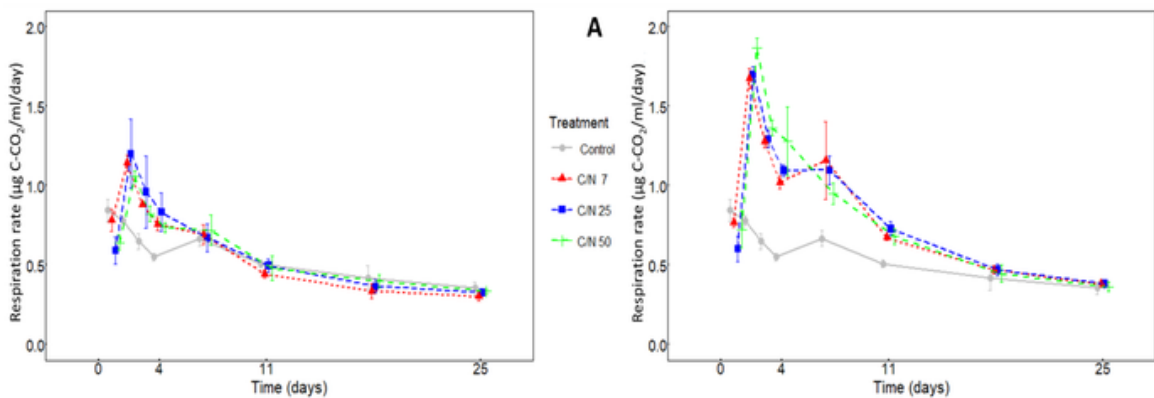

B

Treatment

$+\mathrm{CN} 7$

$-\mathrm{CN} 25$

+ CNso
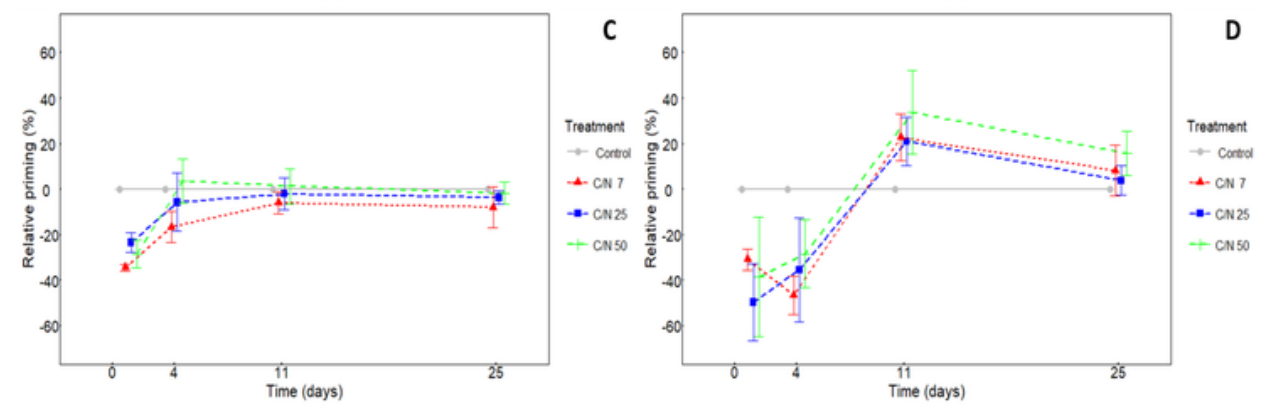

\section{Figure 1}

Respiration rate of control samples and samples amended by artificial exudates with different $\mathrm{C} / \mathrm{N}$ ratios $\mathrm{A} /$ in concentration of $2 \%$ of total DOC and B/ in concentration of $5 \%$ of total DOC during 25 days incubation. C/ Relative priming effect on DOC induced by artificial exudates with different $\mathrm{C} / \mathrm{N}$ ratios in concentration of $2 \%$ of total DOC and D/ in concentration of $5 \%$ of total DOC during 25 days incubation (means, \pm standard deviations, $n=4$ ) 

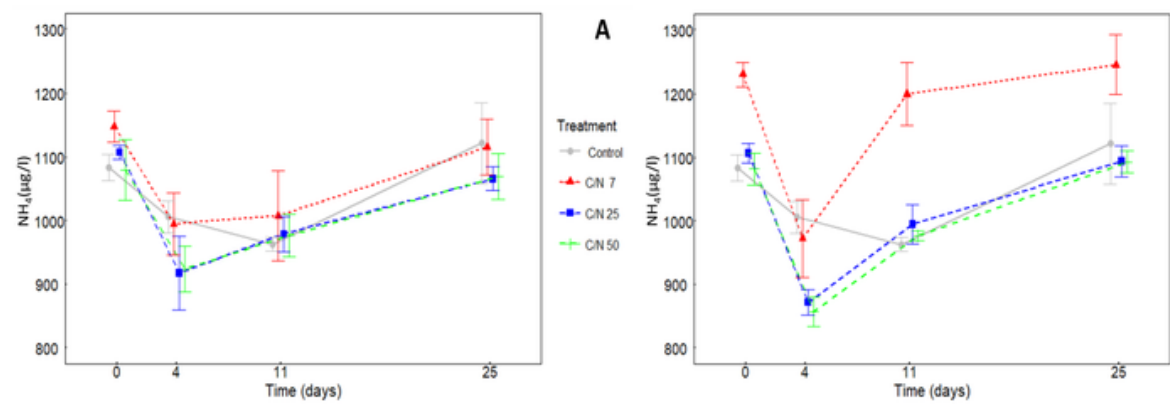

B
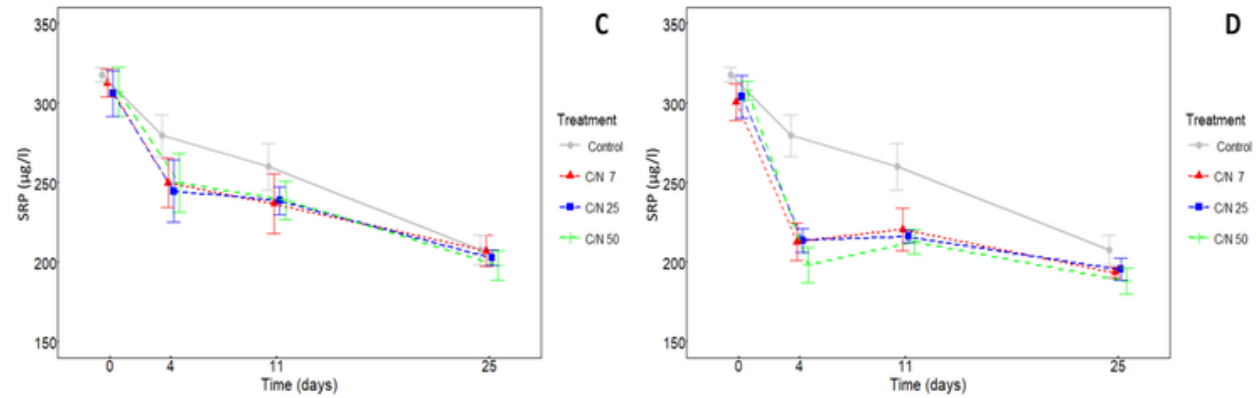

\section{Figure 2}

Ammonium $\mathrm{N}(\mathrm{NH} 4)$ concentration in control samples and samples amended by artificial exudates with different $\mathrm{C} / \mathrm{N}$ ratios $\mathrm{A} /$ in concentration of $2 \%$ of total $\mathrm{DOC}$ and $\mathrm{B} /$ in concentration of $5 \%$ of total DOC during 25 days incubation. C/ Soluble reactive phosphorus (SRP) concentration in control samples and samples amended by artificial exudates with different $\mathrm{C} / \mathrm{N}$ ratios in concentration of $2 \%$ of total DOC and D/ in concentration of $5 \%$ of total DOC during 25 days incubation (means, \pm standard deviations, $n=4$ ) 

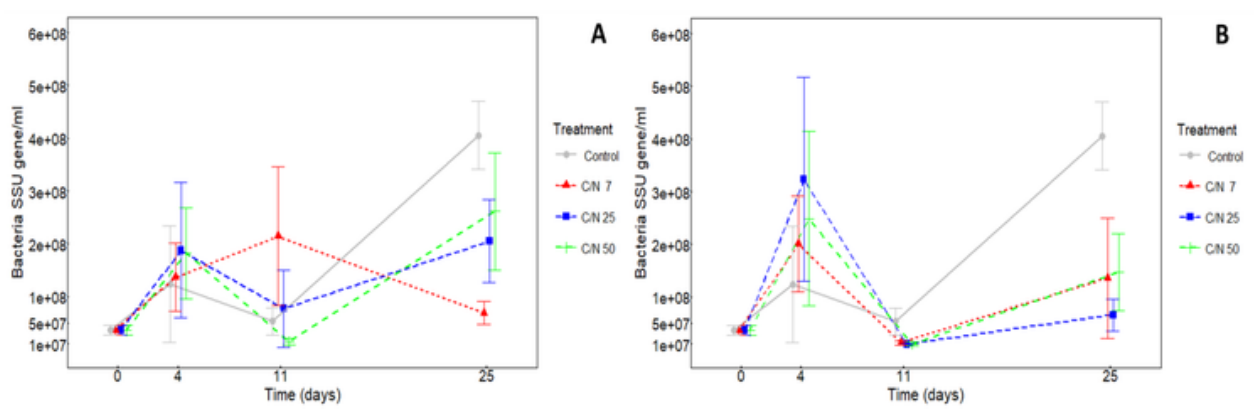

\section{Figure 3}

Bacteria SSU gene (per $\mathrm{ml}$ ) in control samples and samples amended by artificial exudates with different $\mathrm{C} / \mathrm{N}$ ratios $\mathrm{A} /$ in concentration of $2 \%$ of total $\mathrm{DOC}$ and $\mathrm{B} /$ in concentration of $5 \%$ of total DOC during 25 days incubation (means, \pm standard deviations, $n=4$ ) 

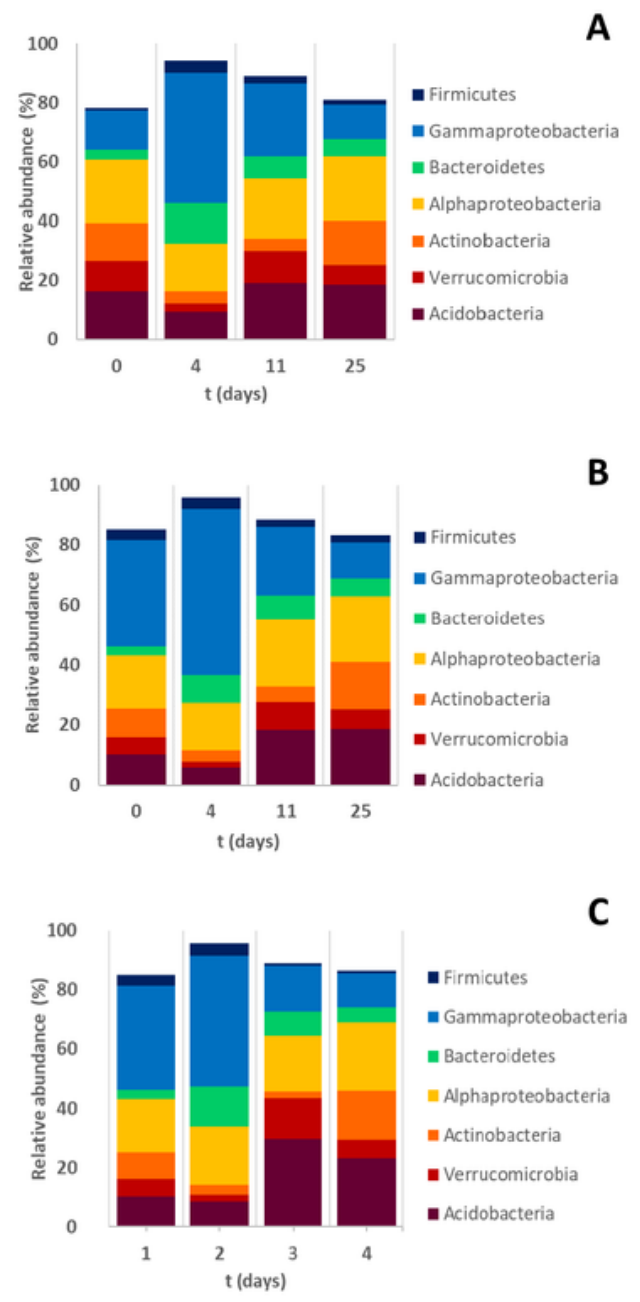

\section{Figure 4}

The relative abundance of the main phyla and classes in samples amended by artificial exudates in concentration of $\mathrm{A} / 2 \%$ of total DOC, B/ $5 \%$ of total DOC and C/ control during 25 days incubation 

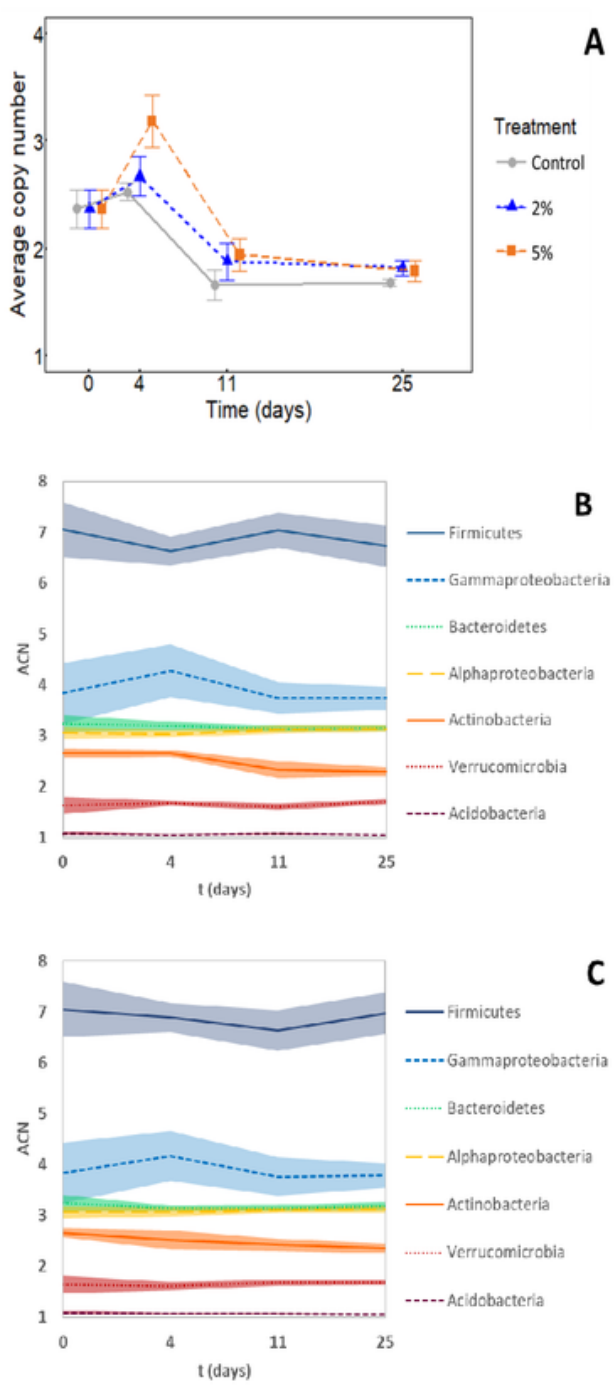

\section{Figure 5}

$\mathrm{A} / \mathrm{r}$ and $\mathrm{K}$ strategists in microbial community according to average 16rRNA copy number per genome (ACN) in control and samples amended by artificial exudates in concentration of $2 \%$ and $5 \%$ of total DOC during 25 days incubation. B/ Changes in each particular bacterial phylum in samples amended by artificial exudates in concentration of $2 \%$ of total DOC during 25 days incubation and $\mathrm{C}$ / in concentration 
of $5 \%$ of total DOC during 25 days incubation. Enhanced ACN in the prokaryotic community indicates increased abundance of $r$-strategic species (means, \pm standard deviations, $n=12$ )
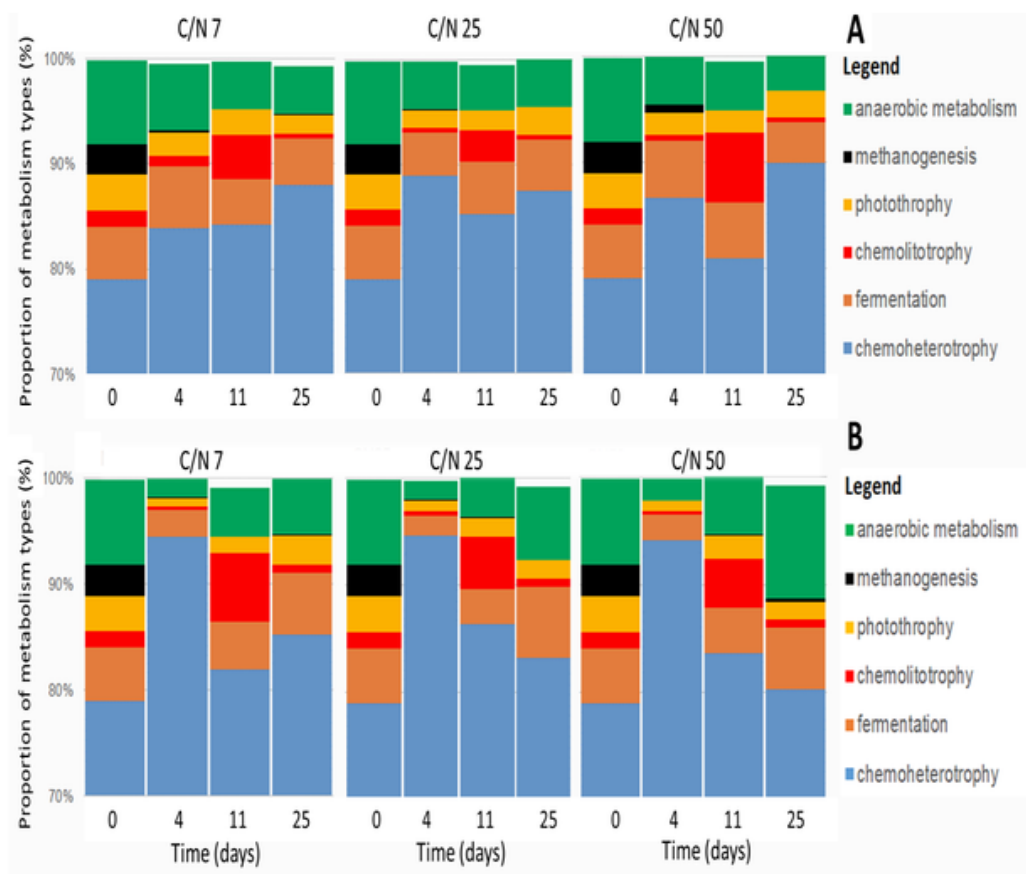

B

Legend

nanaerobic metabolism

methanogenesis

uphotothrophy

- chemolitotophy

I fementation

chemoheterotophy

\section{Figure 6}

Temporal development of metabolism types of prokaryotic community in samples amended by artificial exudates with different $\mathrm{C} / \mathrm{N}$ ratios $\mathrm{A} /$ in concentration of $2 \%$ of total $\mathrm{DOC}$ and $\mathrm{B} /$ in concentration of $5 \%$ 
of total DOC during 25 days incubation. Type of metabolism was assigned according to known bacterial genomes using FAPROTAX algorithm [39]

\section{Supplementary Files}

This is a list of supplementary files associated with this preprint. Click to download.

- Additionalfile6.docx

- Additionalfile2.pdf

- Additionalfile5.docx

- Additionalfile4.docx

- Additionalfile7.docx

- Additionalfile3.pdf

- Additionalfile1.pdf 